\title{
FRAKTUR AKIBAT OSTEOPOROSIS
}

\author{
${ }^{1}$ Yulianingsih Syam \\ ${ }^{2}$ Djarot Noersasongko \\ ${ }^{2}$ Haryanto Sunaryo
}

\author{
${ }^{1}$ Kandidat Skripsi Fakultas Kedokteran Universitas Sam Ratulangi Manado \\ ${ }^{2}$ Bagian Bedah Fakultas Kedokteran Universitas Sam Ratulangi Manado \\ Email: Syamulie26@gmail.com
}

\begin{abstract}
This thesis to find out thypes of fractures due to osteoporosis, complementary examination to diagnose osteoporosis, and treatment of osteoporosis general. The contents of thus thesis aimed to reduce the occurrence of fracture due to osteoporosis. Metods used in this thesis is the collection of reference materials and data on fracture due to osteoporosis from text book journals, magazines, and the internet. The result obtained it is influenced by the hormone estrogen. The number of women threatened Indonesia's increasing osteoporosis caused by such as smoking, alcohol consumption, anda long term use of steroid. Thus knowledge and information about age prematurely. Avidly consume foods high in calcium such as milk and processed milk products, expand activity, often basking in the morning, avoid smoking, as well as avoid consumption of alcoholic beverages
\end{abstract}

Keywords : fracture, osteoporosis, women, calsium, life style.

\begin{abstract}
Abstrak : Skripsi ini bertujuan untuk mengetahui jenis-jenis fraktur akibat osteoporosis, pemeriksaan penunjang untuk mendiagnosis osteoporosis, dan penanganan osteoporosis secara umum. Isi dari skripsi ini ditujukan untuk mengurangi terjadinya fraktur akibat osteoporosis. Metode yang digunakaan dalam skripsi ini yaitu pengumpulan bahan-bahan acuan dan data tentang fraktur akibat osteoporosis yang berasal dari buku teks, jurnal, internet, maupun majalah. Hasil yang didapatkan menunjukkan bahwa osteoporosis merupakan penyakit wanita dibanding pria karena dipengaruhi oleh hormon estrogen. Jumlah wanita yang terancam osteoporosis di Indonesia semakin meningkat yang disebabkan karena kurangnya asupan kalsium dan perubahan gaya hidup seperti merokok, konsumsi alkohol, dan penggunaan steroid jangka panjang. Dengan demikian, pengetahuan dan informasi tentang osteoporosis sangat penting sebagai upaya pencegahan bagi wanita usia dini. Rajin mengkonsumsi makanan berkalsium tinggi seperti susu dan produk olahan susu lainnya, perbanyak aktivitas, sering berjemur di pagi hari, hindari rokok, serta hindari konsumsi minuman beralkohol.

Kata kunci: fraktur, osteoporosis, wanita, kalsium, gaya hidup
\end{abstract}

WHO memperkirakan pada pertengahan abad mendatang, jumlah patah tulang pada panggul karena osteoporosis akan meningkat tiga kali lipat, dari 1,7 juta pada tahun 1990 menjadi 6,3 juta kasus pada tahun 2050 kelak. Data dari International Osteoporosis Foundation (IOF) menyebutkan bahwa seluruh dunia, satu dari tiga wanita dan satu dari delapan pria yang berusia di atas 50 tahun memiliki risiko mengalami patah tulang akibat osteoporosis dalam hidup mereka. Data terbaru dari International Osteoporosis Foundation (IOF) menyebutkan sampai tahun 2000 ini diperkirakan 200 juta wanita mengalami osteoporosis. ${ }^{1}$

Dengan meningkatnya usia harapan hidup, maka berbagai penyakit degeneratif dan metabolik termasuk osteoporosis akan menjadi problem muskuloskeletal yang 
memerlukan perhatian khusus, terutama di negara-negara berkembang, termasuk Indonesia. ${ }^{2}$ Jumlah penderita osteoporosis di Indonesia jauh lebih besar dari data terakhir Depkes, yang mematok angka 19,7 persen dari seluruh penduduk. Catatan di beberapa kota seperti Jakarta, Surabaya, Semarang, Bandung dan Medan bahkan sudah mencapai 30 persen (lebih tinggi dari luar negeri). ${ }^{3}$

\section{DEFINISI}

Osteoporosis adalah gangguan tulang yang ditandai dengan penurunan massa tulang dan kemerosotan mikro-arsitektur yang menyebabkan tulang menjadi rapuh dan mudah patah, kemerosotan mikroarsitektur tampak sebagai spikulum tulang yang semakin sedikit dan tipis serta adanya "topangan” horizontal abnormal yang tidak menyatu untuk membentuk trabekul. ${ }^{4}$

Definisi standar oleh WHO adalah $a$ skeletal disorder characterized by compressed bone strength prediposting a person to an increased risk of fracture, yaitu tulang yang rapuh hingga mudah terjadi patah tulang. ${ }^{3}$

Banyak faktor yang dapat mempengaruhi terjadinya osteoporosis, antara lain usia yang menyangkut kadar hormon steroid kelamin endogen, genetik, kebiasaan berolah raga, konsumsi alkohol, rokok, kualitas diet, penggunaan kronis obat-obatan (glukokortikoid, tiroid). ${ }^{5}$

\section{PENGELOMPOKAN OSTEOPOROSIS}

\section{Osteoporosis primer}

Terjadi pada wanita pascamenopause dan pada wanita usia lanjut. Pada wanita biasanya disebabkan oleh pengaruh hormonal yang tidak seefektif biasanya. Hormon estrogen yang berfungsi melindungi tulang dalam tubuh malah berkurang jumlahnya. Osteoporosis primer pada wanita biasanya disebut sebagai osteoporosis postmenopausal. Sementara itu, pada pria osteoporosis primer yang terjadi adalah osteoporosis senilis. Osteoporosis ini terjadi karena berkurangnya kalsium akibat penuaan usia. Osteoporosis senilis juga bisa terjadi pada wanita. Jadi, wanita yang sudah lanjut usia bisa terkena osteoporosis senilis dan postmenopausal. Pada kenyataannya, jumlah penderita osteoporosis wanita lebih banyak daripada jumlah penderita pria. ${ }^{6}$

Faktor-faktor terjadinya: ${ }^{7}$

- Umur (banyak terjadi pada usia lanjut)

- Jenis kelamin (lebih sering wanita dibandingkan pada pria)

- Ras (lebih banyak terjadi pada orang timur dan kulit putih dibandingkan dengan orang kulit hitam atau negro)

- Kehamilan (lebih banyak terjadi pada wanita yang mempunyai banyak anak)

- Postur tubuh (lebih berisiko pada postur tubuh gemuk daripada tubuh kurus)

- Keluarga (seseorang lebih berisiko mendapat osteoporosis bila ada kaitan keluarga yang menderita osteoporosis

- Makanan (mereka yang makanan sehari-harinya kurang zat kapur lebih berisiko mendapat osteoporosis dibandingkan dengan yang diet sehari cukup Ca).

- Pola hidup sehat (mereka yang pola hidup sehat lebih kurang berisiko menderita osteoporosis dibandingkan dengan yang menerapkan pola hidup sehari-hari yang sembarangan)

\section{Osteoporosis Sekunder}

Osteoporosis sekunder disebabkan oleh penyakit tertentu, gangguan hormonal, dan juga kesalahan pada gaya hidup seperti konsumsi alkohol secara berlebihan, rokok, kafein, dan kurangnya aktivitas fisik berbeda dengan osteoporosis primer yang terjadi karena faktor usia, osteoporosis sekunder bisa saja terjadi pada orang yang masih berusia muda. Jadi, perhatian terhadap penyakit ini sebaiknya tidak hanya difokuskan pada orang tua saja. Orang yang masih muda pun bisa terkena osteoporosis. Sayangnya, banyak orang yang tidak menyadari hal tersebut dan malah melakukan gaya hidup yang bisa meningkatkan faktor risiko terkena osteoporosis. Bukan hanya ia bisa lebih rentan terkena 
osteoporosis di saat tua, ada kemungkinan pula ia terserang di usia muda. Osteoporosis sekunder yang berkaitan dengan penyakit juga ditemukan pada orang yang mengidap penyakit cushing disease (kelainan hormon karena tingginya kortisol dalam darah), hipertiroid (kelebihan hormon tiroid), hiperparatiroid, gangguan ginjal kronis, anoreksia nervosa, dan beberapa penyakit lain. ${ }^{6}$

\section{Osteoporosis pada nnak}

Ada kalanya osteoporosis terjadi pada anak-anak atau orang dewasa yang usianya masih muda. Biasanya penyebab osteoporosis jenis ini berkaitan dengan osteoporosis sekunder. Meskipun begitu, ada pula osteoporosis pada anak dan remaja yang belum diketahui penyebabnya. Osteoporosis ini disebut sebagai osteoporosis juvenile idiopatik. Kadar nutrisi dalam tubuh penderitanya juga normal dan baik-baik saja. Selain itu, kadar hormonal mereka termasuk kadar normal. Jumlah penderita osteoporosis juvenile idiopatik termasuk sedikit dan jarang ditemukan. Sampai sekarang belum diketahui apa yang bisa menyembuhkan penyakit ini. Obat-obatan dan terapi yang diberikan biasanya cocok untuk orang dewasa atau sudah tua. Selain itu, mereka pun harus menghindari aktivitas fisik yang mampu membuat tulang mereka retak. Bantuan seperti tongkat penyangga kadang dibutuhkan oleh anak-anak ini. ${ }^{6}$

\section{Oteoporosis pada laki-laki}

Osteoporosis pada laki-laki, seringkali kurang diperhatikan dibandingkan dengan osteoporsis pada wanita. Pada dewasa muda, insidens fraktur ternyata lebih tinggi pada laki-laki daripada wanita; hal ini dihubungkan dengan insidens trauma yang lebih tinggi pada laki-laki daripada wanita. Dengan bertambahnya umur, insidens fraktur pada panggul makin meningkat, tetapi peningkatan insidens fraktur pada laki-laki lebih lambat 5-10 tahun dibandingkan wanita. Pada laki-laki, dengan bertambahnya umur, maka tulang kortikal akan makin menipis, tetapi penipisan ini tidak secepat pada wanita, karena laki-laki tidak pernah mengalami menopause. Selain itu, pada laki-laki kehilangan massa tulang lebih bersifat penipisan, sedangkan pada wanita lebih diakibatkan oleh kehilangan elemen trabekula dari tulang pada laki-laki juga lebih besar daripada wanita. ${ }^{2}$

\section{GEJALA OSTEOPOROSIS}

Osteoporosis dapat muncul tanpa sengaja selama beberpa dekade karena osteoporosis tidak menyebabkan gejala sampai terjadi patah tulang. Selain itu, beberapa fraktur osteoporosis dapat lolos deteksi selama bertahun-tahun karena tidak memperlihatkan gejala. Gejala yang berhubungan dengan patah tulang osteoporosis biasanya adalah nyeri. Lokasi nyeri tergantung pada lokasi fraktur. Gejala osteoporosis pada pria mirip dengan gejala osteoporosis pada wanita. $^{8}$

Kepadatan tulang berkurang secara perlahan, sehingga pada awalnya osteoporosis tidak menimbulkan gejala. Beberapa penderita tidak memiliki gejala. Biasanya gejala timbul pada wanita berusia 51-75 tahun, meski bisa lebih cepat ataupun lambat. Jika kepadatan berkurang sehingga tulang menjadi kolaps atau hancur, maka akan timbul nyeri tulang dan kelainan bentuk. Beberapa kasus yang sering terjadi adalah: ${ }^{9}$

1. Kolaps tulang belakang menyebabkan nyeri punggung menahun. Kolaps secara spontan karena cedera ringan ini biasanya menimbulkan nyeri secara tibatiba di bagian tertentu punggung. Nyeri makin berat jika penderita berdiri, berjalan, atau disentuh. Nyeri ini perlahan-lahan menghilang dalam waktu beberapa minggu atau bulan. Jika ada beberapa tulang belakang hancur, maka akan terbentuk kelengkungan abnormal dari tulang belakang, yang menyebabkan ketegangan otot sakit.

2. Patah tulang lain yang serius adalah patah tulang panggul. Ini bisa diakibatkan oleh benturan ringan atau jatuh. Risiko kematian akibat patah tulang pinggul sama dengan kanker payudara. 
3. Yang juga sering terjadi adalah patah tulang lengan di sambungkan dengan pergelangan tangan, yang disebut fraktur colles.

\section{PENYEBAB OSTEOPOROSIS}

Osteoporosis terjadi karena berbagai sebab, ada yang bisa dihindari tapi ada juga yang tidak. Faktor penyebab yang tidak bisa dihindari antara lain: ${ }^{10}$

1. Keturunan. Bila dari garis keturunan memang ada osteoporosis (misal bungkuk), maka resiko terkena keropos tulang kian besar

2. Usia. Setelah usia 35 tahun kepadatan tulang akan berkurang secara alami.

3. Hormon. Setelah berhentinya haid, perempuan lebih rentan terhadap osteoporosis karena terjadi perubahan hormonal yang dapat menurunkan drastis kemampuan tubuh untuk menyerap kalsium.

4. Postur. Tubuh mungil atau kurus lebih rentan terkena osteoporosis ketimbang mereka yang berpostur gemuk atau besar.

5. Kurang gerakan. Jika kurang berolahraga, terutama olahraga aerobik, dan sangat sedikit melakukan kegiatan fisik.

\section{GAMBARAN KLINIS}

Gejala pada usia lanjut bervariasi beberapa tidak menunjukkan gejala, yang lain seringkali menunjukkan gejala klasik berupa nyeri punggung, yang seringkali dipicu oleh adanya stress fisik, sering akan hilang dengan sendirinya setelah 4-6 minggu. Penderita lain mungkin datang dengan gejala patah tulang, turunnya tinggi badan, bungkuk punggung, yaitu suatu deformitas akibat kolaps dan fraktur pada vertrebral torakal tengah. Fraktur yang mengenai leher femur dan colles sering terjadi sekitar 305 wanita dengan fraktur leher femur menderita osteoporosis. Dibandingkan hanya 15\% pada pria fraktur terjadi bukan saja karena osteoporosis tetapi juga karena kecendurungan usia lanjut untuk jatuh. ${ }^{11}$

\section{DIAGNOSIS OSTEOPOROSIS}

Pada seseorang yang mengalami patah tulang, diagnosis pasti ditegakkan bedasarkan gejala, pemeriksaan fisik, dan rontgen tulang. Pemeriksaan lebih lanjut mungkin diperlukan untuk menyingkirkan keadaan lain yang dapat menyebabkan osteoporosis. Beberapa pemeriksaan yang dapat dilakukan adalah pemeriksaan radiologi, radioisotop, MRI(magnetic Resonance imaging), serta pemeriksaan dengan densitometer (untuk mengetahui kepadatan tulang). Untuk mendiagnosis osteoporosis sebelum terjadinya patah tulang dilakukan pemeriksaan yang menilai kepadatan tulang. Pemeriksaan yang paling akurat adalah DXA (dual-energy x-ray absorptiometry). Pemeriksaan ini aman dan tidak menimbulkan nyeri, serta dapat dilakukan dalam waktu 5-15 menit. ${ }^{12}$

\section{PENGOBATAN OSTEOPOROSIS}

Tujuan pengobatan adalah meningkatkan kepadatan tulang. Semua perempuan, terutama menderita osteoporosis, harus mengonsumsi kalsium dan vitamin $\mathrm{D}$ dalam jumlah yang mencukupi, bifosfat juga digunakan untuk mengomentari osteoporosis. ${ }^{12}$ Pada umumnya orang hanya tahu mengonsumsi kalsium dan vitamin $\mathrm{D}$, atau mengira cukup minum segelas susu sehari, pasti sudah aman dan tulang menjadi kuat. Namun, sebenarnya selain perlu dipadatkan, tulang juga harus dikuatkan. Pengaruh kekurangan hormon dan proses penuaan membuat tulang makin rapuh dan makin tipis. Butuh beberapa jenis obat yang harus dikonsumsi terus-menerus untuk mempertahankan tulang yang sehat.selain pemberian kalsium dan vitamin $\mathrm{D}$, serta mineral dan protein, perlu mengenal obat-obatan untuk osteoporosis, yaitu obat untuk membangun tulang, membuat tulang menjadi makin padat, serta menghambat proses pengeroposan. Obat-obat ini adalah ${ }^{3}$ :

1. Golongan bifosfonat

2. Raloxifene

3. Kalsitonin

4. Tibolone 


\section{Penanganan umum osteoporosis}

Penanganan umum osteoporosis meliputi pengurangan rasa sakit, pemulihan mobilitas, bantuan menghadapi dampak psikososial terhadap penyakit, dan pencegahan berlanjutnya penurunan massa tulang sehingga mengurangi risiko patah tulang. Kebanyakan pengidap osteoporosis merasa lega setelah tahu banyak yang dapat dilakukan untuk mencegah tulang maupun mengatasi gejala yang ada, seperti olahraga, mengubah pola makan, dan mencegah jatuh. Mengetahui bahwa mereka tidak sendirian menderita osteoporosis dan bisa berkomunikasi dengan penderita khusus bagi penderita osteoporosis bisa menjadi sumber informasi mengenai semua aspek penyakit ini, selain sarana untuk bertemu dengan penderita lain atau petugas kesehatan yang menangani osteoporosis. ${ }^{13}$

\section{PENCEGAHAN OSTEOPOROSIS ${ }^{14}$}

\section{Asupan kaslium cukup}

Mempertahankan atau meningkatkan kepadatan tulang dapat dilakukan dengan mengkonsumsi kalsium yang cukup. Minum 2 gelas susu dan tambahan vitamin D setiap hari, bisa meningkatkan kepadatan tulang pada wanita setengah baya yang sebelumnya tidak mendapatkan cukup kalsium.

\section{Melakukan olah raga beban}

Selain olahraga menggunakan alat beban, berat badan sendiri juga dapat berfungsi sebagai beban yang dapat meningkatkan kepadatan tulang. Olahraga beban misalnya berjalan dan menaiki tangga.

\section{Gaya hidup sehat}

Tidak ada kata terlambat untuk melakukan gaya hidup sehat. Menghindari rokok dan alkohol memberikan efek signifikan dalam menurunkan resiko osteoporosis.

\section{Paparan sinar UV B matahari}

Sinar matahari UV B membantu tubuh menghasilkan vitamin D yang dibutuhkan oleh tubuh dalam pembentukan massa tulang.

\section{SIMPULAN}

Osteoporosis adalah gangguan tulang yang ditandai dengan penurunan massa tulang dan kemerosotan mikro-arsitektur yang menyebabkan tulang menjadi rapuh dan mudah patah, kemerosotan mikroarsitektur tampak sebagai spikulum tulang yang semakin sedikit dan tipis serta adanya “topangan” horizontal abnormal yang tidak menyatu untuk membentuk trabekul. Menurut WHO adalah a skeletal disorder characterized by compressed bone strength prediposting a person to an increased risk of fracture, yaitu tulang yang rapuh hingga mudah terjadi patah tulang.

Faktor yang dapat mempengaruhi terjadinya osteoporosis, antara lain usia yang menyangkut kadar hormon steroid kelamin endogen, genetik, kebiasaan berolah raga, konsumsi alkohol, rokok, kualitas diet, penggunaan kronis obat-obatan (glukokortikoid, tiroid).

Osteoporosis dapat muncul tanpa gejala. Tujuan pengobatan adalah meningkatkan kepadatan tulang. Perempuan pascamenopause yang menderita osteoporosis juga mendapatkan estrogen (biasanya bersama dengan progesteron) atau alendronat, yang dapat memperlambat atau menghentikan penyakitnya

\section{DAFTAR PUSTAKA}

1. Hartono M. Mencegah dan Mengobati Osteoporosis. Jakarta : Puspa Swara, 2004 ; Hal V

2. Setiyohadi B. Osteoporosis. In: Sudoyo WA, Setiyohadi B, Alwi I, Simadibrata KM, Setati S. Editors. Buku Ajar Ilmu Penyakit Dalam Jilid III Ed. 5. Jakarta : Interna Publising, 2009. Hal ; 2650

3. Tandra H. Segala Sesuatu Yang Harus Anda Ketahui Tentang Osteoporosis Mengenal Mengatasi dan Mencegah Tulang Keropos. Jakarta : PT Gramedia Pustaka Pratama, 2009 ; Hal 3-4, 6

4. Dennis KB, Ninay K. Sistem Muskuloskeletal. In Robbins, Kumar, 
Cotran. Buku Ajar Patologi. Ed 7 Vol 2. Jakarta EGC, 2007 ; Hal 846

5. Gunawan SG, Setiabudy R, Nafrialdi, Elysabeth. Farmakologi dan Terapi, Ed 5. Jakarta : FKUI, 2007 ; Hal 450, 452-453

6. Tjahjadi V. Buku Kesehatan Praktis Mengenal Mencegah Mengatasi Silent Killer Osteoporosis. Jakarta : Pustaka Widyamara, 2002 : Hal ; 2,3,4, 98-100, 146

7. Yatim F. Osteoporosis (Penyakit Kerapuhan Tulang Pada Manula). Jakarta : Pustaka Populer Obor, 2003 ; Hal 13

8. Shanty M. Silent Killer Disease Penyakit Yang Diam-diam Mematikan. Jogjakarta : Javalitera, 2011 ; Hal 79-80

9. Sarasvati. Cara Holistik Dan Praktis Atasi Gangguan Khas Pada Kesehatan Wanita. Jakarta Buana Ilmu Populer, 2009 ; Hal 1718
10. Javier. Kupas Tuntas Osteoporosis Pengenalan Pendekatan Pencegahan dan Pengobatan. Jogjakarta : 2010 ; Hal 23-24

11. Peck, Chesnut. Penyakit Tulang Dan Patah Tulang. in Darmojo RB, Martono H. Dalam Buku Ajar Geriatri Ilmu Kesehatan Lanjut Usia. Jakarta : FKUI, 2011 : Hal 263

12. Junaidi I. Osteoporosis Pengenalan Pencegahan Serta Pengobatan Penyakit Osteoporosis dan Penyakit Tulang Lain Yang Mirip. Jakarta : PT Bhuana Ilmu Populer, 2009 ; Hal 2, 7-8, 9, 36-3

13. Compston J. Seri kesehatan bimbingan dokter anda osteoporosis. Jakarta : Dian Rakyat, 2002 ; Hal; 42

14. All about pharmacy. osteoporosis [homepage on the internet]. Nodate [cited 2011 Sep 20]. Available from : http://iyankchemiztry.blogspot.com/2010/12 /osteoporosis.html?/. 